\title{
THEOLOGICAL RESPONSES TO AMARNA
}

\author{
Jan Assmann
}

There is no doubt that the post-Amarna and Ramesside ages reacted in many ways to the Amarna experience. "Response," however, means more than reaction. It refers to a continuity of discourse centered around a central set of problems. The paper attempts to reconstruct the theological debate of the New Kingdom and its main issues. Within this frame, two salient phenomena of Ramesside theology stand out as being related to the Amarna religion in the way of of "response:" the "Ba-theology" of Amun which interprets the cosmos as the body of a hidden god who animates it from within, and the movement of personal piety that interprets not only cosmic, but individual life including destiny and history as emanating from god's will who in this aspect acts as judge and saviour. I dedicate this paper to my friend Donald B. Redford as a token of my indebtedness to his groundbreaking research on Akhenaten and his time.

Akhenaten's monotheistic revolution met with two different kinds of responses. One is practical and consists in the dismantling of his buildings, effacement of his traces and elimination of his name from the king list. The other one is intellectual and consists in changes in the worldview and basic ideas of god which seem to react to Akhenaten's revolutionary ideas. Both responses were slow and stretched over several subsequent reigns, starting with Tutankhamun and ending only under Ramesses II. The following paper deals with the second response, the intellectual or theological reaction. It meets with the problem of implicitness. There is no explicit refutation or discussion of Akhenaten's ideas. The name is, of course, never mentioned. But even allusions are missing. ${ }^{1}$ The very notion of "heresy" seems to be alien to Egyptian theology. There is no possibility of distinguishing between truth and error in matters of religion, no orthodoxy. There-

${ }^{1}$ With the famous exception of the inscription of Mes in which, for juridical reasons, it was impossible to skip his reign in simply ascribing it to Amenophis III or Horemheb. In this inscription he is alluded to as "the criminal of Akhetaten," A. H. Gardiner, JEA 24 (1938) 124; Donald B. Redford, Akhenaten: The Heretic King (Princeton, Princeton University Press, 1984) 231. 
fore, the theory of a connection between post-Amarna and Ramesside theological developments and Amarna religion cannot be more than a hypothesis.

Very much the same, however, applies to Amarna religion itself. Akhenaten reacted in the same manner against traditional religion, by practical persecution (closing temples, effacing names in inscriptions, destroying representations such as the Sem-priest) and by implicit theological opposition. Even here, there is no explicit refutation. We are far away from the theological debates of early Christianity, but far away also from what can be found in terms of polemical antagonism in the Zoroastrian Gathas and in some biblical texts concerning the idolators. Akhenaten rejects or discards the traditional image of the world by silently putting a different one in its place.

A closer look into Akhenaten's hymns shows, however, that his relation to tradition is complex and ambivalent. He is both a continuer and a revolutionary. He continues a trend that is already manifest in older texts such as the Cairo Hymn to Amun, dating back perhaps to the Late Middle Kingdom or Second Intermediate Period and in the Suty and Hor hymn (the "New Solar Theology") and he is revolutionary in radicalizing this same trend in a way that it excludes traditional polytheism. ${ }^{2}$ A similar complexity may be observed with regard to the relationship between Amarna and post-Amarna theology. There is both continuity and discontinuity. The post-Amarna and Ramesside theology is everything but a simple return to orthodoxy. The innovative character of this theology and its difference from traditional pre-Amarna texts is evident. It breaks with Amarna monotheism or exclusivism ("mono-atonism") but it obviously continues a trend towards stressing the Oneness of the Divine which marks the New Solar Theology, "explodes" in Amarna theology and still remains the major theme in post-Amarna and Ramesside theology.

A last preliminary remark concerning the term "theology." Are we entitled to use that term, given the fact that there is no explicit dispute and refutation of conflicting theological positions? Are we not misconstruing the course of history if we interpret it as a conflict of ideas instead of parties, politics, power, economy, ritual and other more tangible factors? I am not denying the importance of these tangible factors. And I am fully aware of the fact that the continuity of ancient

\footnotetext{
${ }^{2}$ See my Egyptian Solar Religion in the New Kingdom: Re, Amun, and the Crisis of Polytheism (London: Kegan Paul, 1995) 67-101.
} 
Egyptian civilization was not predominantly a matter of textual tradition, learning, interpreting, transmitting the classics, such as in China, India, Zoroastrian Persia, Second Temple Judaism and Alexandrinian Hellenism. In Egypt, the pragmatics of religion, rituals, feasts, priesthood, always remained dominant over against semantics, that is, texts and interpretations. I am not advocating a view of ancient Egyptian religion that turns it into a discourse, let alone an orthodoxy.

Yet the texts are there and their undeniable presence has to be accounted for. Moreover, the 300 years surrounding the Amarna period, starting 100 years earlier with Hatshepsut and Thutmosis III and ending 200 years later with Ramesses III confront us with an unprecedented proliferation of texts dealing with matters divine; hundreds of hymns especially to the sun-god and to Amun-Re, but also to Ptah, Osiris and other gods are preserved on tomb walls and on papyri. This proliferation of theological discourse shows the prime importance of religious ideas during this particular period that entitles us to use the term "theology." This textual phenomenon is not just a matter of proliferation but of a continuity of some central problems and topics. This is the decisive and defining factor that turns a corpus of disparate texts into a "discourse." We are dealing with a discursive process, a continuous elaboration and evolution of ideas. We are able to define and distinguish pre-Amarna from post-Amarna positions, post-Amarna from Ramesside theology, early Ramesside from late Ramesside ideas. This discursive continuity is what I am referring to in using the terms "response" and "theology."

In the following paper, I shall first characterize the central problem, that defines the identity and continuity of the theological discourse or debate of the New Kingdom, then proceed to the main solutions or positions that can be discerned within the corpus of texts and finally reconstruct the ways in which the Ramesside position may be interpreted as a response to the Amarna position.

\section{God and the Gods, Creator and Creation: The Central Problem}

The central problem underlying the theological discourse of the New Kingdom is the relationship between the One god and the many gods on the one hand, and God and world, or creator and creation, on the other hand. Both these relations are just aspects of the same question, because the gods and their constellations and cooperations constitute the world in Egyptian thought. Theogony and cosmogony 
are the same. Thus, the relationship between the One god and the many gods is traditionally expressed in terms of creation. The one God, Atum, the personification of preexisting Oneness, creates the world by engendering Shu and Tefnut (what I interpreted as air and fire $^{3}$ or primordial light), who engender Geb and Nut (heaven and earth), the parents of the five children of Nut who prolong cosmic reality into the institutions of civilization and human history. This same sequence of generations corresponds also to a succession of rulers. Re-Atum, the first tenant of kingship, hands over the office to Shu, who, in his turn, is succeeded by Geb. Every passage of rulership, from $\mathrm{Re}$ to Shu and from Shu to Geb, is marked by a severe crisis. The first crisis leads to the separation of heaven and earth and gods and mankind as related in the Book of the Heavenly Cow ${ }^{4}$ and the second to a kind of oedipal conflict between Shu, Geb and Tefnut. ${ }^{5}$ The third crisis, however, is the most decisive and important one, because it forms the myth of the state and the model of pharaonic history: the succession of Geb first by Osiris, then of Horus and Seth, and finally by Horus alone. Seen in this light, cosmogony appears as "cratogony," the emergence and evolution of power. The present situation is characterized by the task of maintaining the world in form of a partition of labour between Re in heaven, Osiris in the underworld and Horus, that is, the reigning pharaoh, on earth. I am referring, of course, to the cosmogony of Heliopolis. ${ }^{6}$ There are, to be sure, many other models such as, for instance, the Hermopolitan one, in which we meet with the eight personifications of preexistent Chaos in whose midst the sun-god is emerging from the mud on a lotus-flower or from the primordial egg, ${ }^{7}$ or the Memphite model, where creation starts with the appearance of the primordial hill out

${ }^{3}$ The goddess Tefnut is conventionally interpreted as 'moisture' for which there is not the slightest evidence. Instead, she is often associated, in the texts, with flames and fire.

${ }^{4}$ E. Hornung, Der Ägyptische Mythos von der Himmelskuh: Eine Ätiologie des Unvollkommenen (OBO 46; Friburg: Universitätsverlag, 1982).

${ }^{5}$ Th. Schneider, "Mythos und Zeitgeschichte in der 30. Dynastie. Eine politische Lektöre des 'Mythos von den Götterkönigen,"' in Andreas Brodbeck (ed.), Ein Ägrptisches Glasperlenspiel: ägyptologische Beiträge für Erik Hornung aus seinem Schülerkreis (Berlin: Gebr. Mann, 1998) 207-42; U. Verhoeven, "Eine Vergewaltigung? Vom Umgang mit einer Textstelle im Naos von El-Arish," in: E. Graefe and U. Verhoeven (ed.), Religion und Philosophie im Alten Ägypten (Leuven: Peeters, 1991) 319-30.

${ }^{6}$ For this tradition see Susanne Bickel, La cosmogonie Égyptienne avant le Nouvel Empire (Fribourg: Editions universitaires, 1994).

${ }^{7}$ Kurt Sethe, "Amun und die acht Urgötter von Hermupolis," APAW 1929. 
of the waters of preexistence and where Ptah precedes the sun god in the execution of rulership. However, all these models are secondary with respect to the Heliopolitan one which serves in Egypt as a "Great Tradition."

Common to all these models is the predominance of creation in explaining the relationship between the One and the many or of God and the world. This is what I have called, using a term coined by Kenneth Burke, the "temporizing of essence." The most important epithet of the highest god in Egypt, the quality that distinguishes him from the other gods is his temporal firstness. The Egyptian concept of primacy, to be " $m h 3 . t$ " has both a temporal and a hierarchical meaning. To be the first means to be the chief. In a way, the first one contains in his essence, in a seminal way, all that comes later. This aspect of firstness is very prominent in Egyptian thought. The name Atum means "to be complete" in this very sense of primordial or preexistent firstness. By turning from creator to maintainer, however, the first and highest god has to resign, in a certain way, his all-encompassing, absorbent and omnipotent position vis-à-vis the other gods. This is a purely theological problem, the problem of synkatabasis, condescendence, with which all major theologies, Hebrew, Christian, Greek etc. were confronted. Creation turns into cooperation. Oneness is the quality of chaos or preexistence, whereas existence and cosmos are characterized by difference, diversity, antagonism and cooperation. ${ }^{8}$ The task of maintaining the world requires a certain diminishing of distance. Maintenance is team work. The One must become a partner. The leading model for expressing the maintenance of the world in terms of cooperation and partnership is the mythology of the Solar Course which shows the sun god sailing in a boat through the sky and the underworld, an action in which virtually all of the gods take part. ${ }^{9}$ This cyclical process is both a process of biological regeneration, which the sun god passes through as a new born child, a young man, an old man and a dead person, and a process of political triumph, in which the sun god is constantly defeating Apophis, the personification of chaos. In both aspects, being subject to periodical death and rebirth, and being confronted by a counter-power of chaos, the sun god as maintainer of the world differs from the sun god as creator of the world.

${ }^{8}$ As has been shown by Erik Hornung in his classic, Conceptions of God in Ancient Egypt: The One and the Many (trans. John Baines; Ithaca: Cornell University Press, 1982 [German original 1971]).

${ }^{9}$ See my Solar Religion, 38-66. 
God in Face of his Creation (including the Gods): New Solar Theology

During the 18th dynasty, this traditional cooperative model of the solar circuit gave way to a different model, whose main tendency is to increase the distance between god and gods or god and world. Now, the sun god is no longer shown as a partner in a cooperative action, embedded in varying constellations of gods, submitted to the sequence of life and death and confronted by a counteracting foe. Rather, he circulates around the world on a solitary course and maintains the world in a way that is very similar if not identical to primordial creation. Thus we read in a sun hymn on a pre-Amarna stela:

You have settled very remote, very far away you have revealed yourself in heaven in your aloneness Every god on earth their arms are held out in praise at your rising You shine, and they see they raise themselves, their arms bent in respect before your display of power. ${ }^{10}$

A very similar view of the relationship between god and world can be found in the Cairo Amun Hymn ${ }^{11}$ and the Suty Hor Stela. ${ }^{12}$ The traditional constellations have disappeared. The god confronts the world in sublime solitude. The distance between god and world has become extreme.

\section{The God in Face of his Creation \\ (excluding the Existence of other Gods): Amarna Theology}

The model of the New Solar Theology comes already very close to the Amarna model, which is only its radicalization. Akhenaten's innovations are: 1) the complete disappearance of the gods, who, in the context of the new solar theology, belong to the world which the sun god

${ }^{10}$ Leiden V $70=\ddot{A H} G$ no. 90; Leiden K 11 = Kitchen, RI III, 175, 2-5.

${ }^{11}$ AHG 87 = pKairo 58038 (formerly pBoulaq 17), ed. A. Mariette, Les Papyrus Égyptiens du musée de Boulaq II (Paris, 1872), pl. xi-xiii, Nr. 17.

${ }^{12} \ddot{A H G} 89$ = BM 826. Edwards, HT VIII, 22-25, pl. xxi; Urk IV, 1943-1946; Fecht, in Z̈̈S 94 (1967) 25-50. 
creates and maintains, 2) the complete elimination of the topic of creation, that is, the distinction between creation and maintenance is definitely abolished in favour of, 3) a "pantheistic" concept of continuous creation and participation, using the topic of "One and million" and the term kheperu, "transformations:"

You create millions of forms (kheperu) from yourself, the One,

Cities and towns

Fields, paths and river ${ }^{13}$

The "million kheperu" refer obviously to the visible world in its aspect of a space made habitable by light and arranged into a cosmos. Yet the Shorter Hymn opposes the One and the Millions as aspects of God himself:

You made heaven remote to rise in it

To see all that you created, you being alone

But there being millions of lives in you (for you) to make them live. ${ }^{14}$

In contrast to the Cairo Hymn, but perhaps in conformity with the latest stage of New Solar Theology, the concept of the sun god is radically heliomorphic and loses every ethical aspect. Aton or Yati acts no longer as a judge,

who hears the supplications of the oppressed,

whose heart inclines towards him who calls unto him,

who rescues the fearful from the hand of the violent,

who judges between the poor and the rich. ${ }^{15}$

Aton is no longer the judge. In the context of the New Solar Theology, one could still speak of $j t n=k$ "thy disk," implying a distinction between the god and the sun. In Amarna, this has become impossible.

${ }^{13}$ Sandman, Texts, 95, 12-13. On this passage, see G. Fecht, ZÄS 94 (1967) 33; J. Assmann, Sonnenhymnen in thebanischen Gräbern (Mainz am Rhein: P. von Zabern, 1983), Text 54 (x).

${ }^{14}$ Sandman, Texts, 15, 1-9; Assmann, Sonnenhymnen, Text 253(s).

15 pCairo CG 58038, iv, 3-5; Assmann, Solar Religion, 125. See also Merikare, 130-38; Assmann, Solar Religion, 119f.; idem, Ma'at: Gerechtigkeit und Unsterblichkeit im Alten Ägyten (Munich: C. H. Beck, 1990) $234 \mathrm{f}$. 


\section{The God Animating his Creation (including the Gods): Post-Amarna and Ramesside Theology}

The hymns of the post-Amarna-period readmit the gods into the world. The restoration inscriptions of Tutankhamun and of Ay stress this point as the most important one. Tutankhamun proclaims to have restored, restaffed and reopened the deserted temples, and Ay confirms to have taken care that everybody is able to worship his deity. ${ }^{16}$ This is a clearly restorative move. But it is also evident that the world-view of the New Solar Theology is not discarded along with its Amarna radicalization, but continued and further elaborated after Amarna. The hymns continue stressing the distance and solitude of the solar creator and maintainer of the world. Creation or cosmogony becomes the major topic again or even more important than ever before. But besides creation, a new model is used to express the god-world or god-gods-relationship. This is the $B a$ concept.

$B a$, the Egyptian word which we translate as "soul" is a bifocal term. It denotes both the sensible manifestation of an invisible power - in this conventional sense, attested already in the Coffin Texts of the Middle Kingdom, the wind is called the " $B a$ " of Shu or the sun the " $B a$ " of Amun - and the one invisible power, that becomes manifest in a variety of sensible phenomena. In this sense, which is the achievement only of post-Amarna theology, Amun-Re comes to be called the "hidden $B a$ " or the "sublime $B a$ " whose manifestations are either the other gods or the visible cosmos itself. In hymn "200" of the collection of hymns in Pap. Leiden I 350, both aspects of the $B a$ concept are used. Verses 8-11 describe the sun as the $B a$, the visible manifestation, of Amun:

His $b a$, it is said, is the one who is in heaven;

It is he, the one who is in the underworld, who rules the east.

His $b a$ is in heaven, his body in the west,

His image is in the southern Heliopolis and wears his diadem. ${ }^{17}$

The closing verse (28), however, refers to the soul-like hiddeness and namelessness of God:

${ }^{16}$ Inscription in Ay's Rock Temple near Akhmim: P. Kuhlmann, in MDAIK 35 (1979) 165-88.

${ }^{17}$ Jan Zandee, De hymnen aan Amon van papyrus Leiden I 350 (OMRO 28; Leiden: E. J. Brill, 1948) 75-86; Assmann, Solar Religion, 140-42. 
He is $b a$-like, hidden of name like his secrecy.

This is what I call the "model of manifestation." In contrast to the "model of creation," the model of manifestation is not temporizing the god-world-relationship. God is not resigning his sublime 'Oneness' in creating or becoming the world. He remains One, relating to the world in a similar way as the Ba relates to the body, an invisible animating principle. In opposition to the new solar theology. and the Amarna models, however, God is not animating the world from without, in distant contraposition, but from within. This is the great innovation which I propose to interpret as a response to Amarna. To be sure, also restoration is a kind of response. But it means just going back to a discontinued tradition. It is a reaction, but not a real response. It does not take into account what Akhenaten has achieved. The new $B a$ theology does. It responds to Akhenaten by surpassing him. It preserves Akhenaten's de-temporized concept of Oneness by further elaborating his model of manifestation for which Akhenaten has made ample use of the term kheperu and the motif of One-and-million, compare, for example, these lines which we have already quoted from the Great hymn and from the Shorter Hymn opposing God and the world as One and million and relating these poles to each other by calling the world the million kheperu of God, the One:

You create millions of forms (kheperu) from yourself, the One,

Cities and towns

Fields, paths and river.

In the Shorter Hymn, the terms "One" and "Millions" relate to aspects of God himself:

You made heaven remote to rise in it

To see all that you created, you being alone

But there being millions of lives in you to make them live.

Here, the relationship between the One and the millions is not one of manifestation (kheperu) but of animation. God contains millions of lives within himself to animate his millionfold creation. All these formulations try to articulate the paradox of opposition and relation. God and world are brought into the greatest possible distance from each other and simultaneously into the closest possible relationship. Let us now have a look at a Ramesside hymn and see how the same topic is treated some fifty years later: 
Hail, one who makes himself into millions,

Whose length and breadth are limitless! ${ }^{18}$

Power in readiness, who gave birth to himself,

Uraeus with great flame;

Great of magic with secret form,

Secret $b a$, to whom respect is shown. ${ }^{19}$

The antagonistic terms One and millions are here linked by the concept of self-transformation: $j r j s w$ "who made or makes himself into." Millions clearly refers to the world of creation which is interpreted as a transformation of god himself. Creation is emanation. The world is created not out of chaos, nor ex nihilo, but ex Deo, "out of God." This is very close to the Amarna concept. God is limitless. So is the world. God is the world. The following verses oppose two aspects of god, sekhem seped "power in readiness" and ba' sheta' "Secret $\mathrm{Ba}$," the first referring to the sun and the second one referring to the hidden aspect of god as a soul that animates the world from within. In Amarna, the One is the sun, the absolutely and overwhelmingly manifest and visible god opposing and animating the world which has no divinity of its own. In Ramesside Thebes, the One is the absolutely hidden and secret $\mathrm{Ba}$ animating the world from within. Thus, the Ramesside Theology is able both to retain and to surpass the Amarna idea of Oneness.

In this context, the formula of One-and-million returns frequently and in a number of variants. The "Million" are stated to be God's body ${ }^{20}$ his limbs, ${ }^{21}$ his transformation ${ }^{22}$ and even his name: "'million of millions' is his name." ${ }^{23}$ By transforming himself into the million-fold reality, God has not ceased to be one. He is the many in that mysteri-

\footnotetext{
${ }^{18}$ On the concept of the "limitlessness" of god, note the expression, "who concealed himself, whose limits cannot be attained," pLeiden I 344 vso ii, 8-9; Jan Zandee, Der Amunshymmus des Papyrus Leiden I 344, Verso, vol. I (Leiden: E. J. Brill, 1992) 120-26. Cf. pBerlin 3049, 16, 6 and Urk VIII, 116: "whose circuit has no limits."

${ }^{19}$ Papyrus Mag. Harris IV,1-2 = N. de Garis Davies, The Temple of Hibis in ElKhargeh Oasis III, The Decoration, pl. 32,1; $\ddot{A H G ~ N r . ~ 129, ~ 1-6 . ~}$

${ }^{20}$ pLeiden I 344 vso. III, 2-3 = Zandee, Amunshymnus, 168-176.

${ }^{21}$ Emile Chassinat, Le temple d'Edfou 3 (Cairo: Imprimerie de l'institut Français d'archéologie orientale, 1928) 34.9-10.

${ }^{22}$ hprw.fm hhw: stela of Ramesses III = Kenneth A. Kitchen, Ramesside Inscriptions 6 (Oxford: Blackwell, 1969) 452.8.

${ }^{23}$ Urk VIII Ä138b = Kurt Sethe, Thebanische Tempelinschriften aus griechisch-römischer Zeit, ed. Otto Firchow (Berlin: Akademie-Verlag, 1957) 110. Of Yahweh, on the contrary, it is said: "'One' is his name" (Zech 14:9).
} 
ous way, hidden and present at the same time, which this theology is trying to grasp by means of the $b a$-concept. A common text even goes so far as to describe god as the $b a$ (and not the creator) of gods and humans (that is, "the millions"): ${ }^{24}$

The One Alone who created what is,

The illustrious ba of gods and humans. ${ }^{25}$

In my book Moses the Egyptian, I have ventured the idea that this new idea of god is not only a response to Amarna but also the origin of the Hermetic idea of god, le dieu cosmique, deus mundus, a god who is anima mundi and whose body is the world, and that the Ramessidee formula of the "one and the millions" is not only echoing the corresponding Amarna formulations but also anticipating the Hermetic formulations such as Hen to pan, una quae es omnia etc. There is an uninterrupted line of textual tradition from the ramesside age down to the Greco-Roman era. The Ramesside Ba-theology reaches its apex in the Late Period with the cult of the ten Bas in Thebes and El-Hibe. The idea of the world as the incorporation of a soul-like God and of God as a soul animating the world remains central in Egyptian theology even after the New Kingdom and the flourishing of the theological discourse.

\section{The Ethical Aspect: the Rise of "Personal Piety"}

We have seen, that in Amarna theology, the ethical aspect of God as judge and saviour is absent in a most conspicuous way. In Ramesside theology, this aspect is not only restored to its full importance, but even elevated to a much higher level. God the judge and saviour becomes now as central and important an idea of god as God the hidden soul manifesting himself in the pleroma of gods and the cosmic world. This promotion of the ethical aspect of God to prime importance corresponds to the movement called personal piety. This seems more to be a reaction against than a response to Amarna. At first sight, it is not clear which elements of Amarna theology could be retained and developed in the theology of personal piety. There seems only to be discontinuity and no continuity.

\footnotetext{
${ }^{24}$ On this meaning of hhw, see Assmann, Sonnenhymnen, Text 149(c).

${ }^{25}$ Hymn to the primeval god in the "Livre que mon fleurisse," pBerlin 3030 VIII-IX; pLouvre 3336 I.1-16; pBrussels published by Louis Speelers, Rec. Travaux 39 (1917) $28 f f$.
} 
However, a continuity may be discovered if we realize that Aten is not only a god of light, animating the world by his rays, but also a god of time, which he creates and emanates by his motion. "You yourself are lifetime; one lives by you," 26 we read in the Great Hymn. In the context of Amarna religion, time or lifetime is understood in the same way as light, just as a kind of cosmic energy. But from here, it seems only a small step to a more material or historical/biographical conception of lifetime implying the ideas of development, fortune, providence and divine intervention in forms of reward and punishment. Time and history now become a field of religious experience, of divine manifestation. But there is even more. In an article on the Loyalist instruction of Akhenaten, I have studied a text which in Amarna appears as a hymn to the king and which reappears at Thebes addressing the god Khonsu as a prayer of personal piety. ${ }^{27}$ Personal piety can thus be interpreted as inheriting and continuing to a large extent the royal ideology of Amarna. The image of Akhenaten as the personal god of the individual is now taken over by the god who not only creates time, but also determines the events that happen within time.

As Posener has shown, personal piety starts long before Amarna. ${ }^{28}$ In this respect, Amarna religion can be shown to be a reaction against the rise of a movement that threatened the position of the king by establishing a direct contact between god and an individual human being. Amarna religion meant a total cosmicization of divinity. God is the sun and nothing but the sun, animating the world by light and time. God is thus banned from history, politics and personal destiny which become the exclusively royal spheres of activity. The break-down of Amarna religion meant a break-through of personal piety. What Akhenaten opposed now becomes the dominant paradigm. Before Amarna, personal piety may very possibly have been just a local phenomenon, restricted to Thebes and to Theban festivals during which the god Amun appeared to his worshippers. After Amarna, personal piety became the general attitude all over Egypt.

What I call personal piety is, of course, a very specific phenomenon. I am not speaking of popular religion, which, to be sure, is not restricted to the New Kingdom. Unlike popular religion, personal piety

\footnotetext{
${ }^{26}$ Sandman, Texts, 95.17-18. Cf. J. Assmann, Zeit und Ewigkeit im alten Egypt (Heidelberg: C. Winter, 1975) 55.

27 "Die 'Loyalistische Lehre' Echnatons," SAK 8 (1980) 1-32.

28 "La piété personelle avant l'âge amarnien," RdE 27 (1975) 195-210.
} 
is an innovation of the New Kingdom, slowly beginning during the 18th dynasty, triumphantly dominating in the 19th and 20th dynasty and finally overturning the state in the 21 st dynasty. Within this line of development, Amarna has a very specific position and plays an important role. It is possible that without the Amarna experience, this new movement would not have reached this level of overwhelming power.

The god of Ramesside theology can thus be shown to inherit and absorb both the cosmic and the personal god of Amarna theology, both the Aten and the king. Here starts another line of tradition that leads to and culminates in the Hellenistic Era: the concept of Isis-Tyche - the mistress of destiny, a deity both cosmic and personal, incorporating the universe and saving the individual worshiper. 